\title{
THE CONCEPT OF INSTITUTIONALISED DISINTEGRATION: TOWARDS A RECOGNITION OF THE EU INSTITUTIONS ANEW
}

\author{
ALAN ŻUKOWSKI*
}

\section{KEYWORDS}

institutionalised disintegration, European Union law, EU institutions, legal system, legal phenomena

\begin{abstract}
The main purpose of this article is to recognise an ongoing phenomenon of disintegration in legal terms. A specific role of the EU institutions is inevitable because of supranational relations' nature and to-date momentum of public international law. Briefly, disintegration supported by the EU institutions may be the expected solution. Therefore, the concept of institutionalised disintegration is the author's proposal for using the EU acquis to create a new (autonomous) treaty regime of public international law and to define the EU institutions anew. The basis for reconciliation of institutions and disintegration is to constitute the scientific method on so-called legal phenomena that combine dogmas and functions of law in general. Legal phenomena are correlated with de lege ferenda proposals that - mainly critically - react to current challenges. Challenges - in turn - are derived from a de lege lata analysis of the politico-legal system (especially understanding of the institution, mapping of disintegration and examination of legislative methods).
\end{abstract}

* University of Wrocław, Wrocław, Poland, E-mail: alanzukowski1@gmail.com, ORCID: 0000-0002-4724-2942 


\section{INTRODUCTION}

The main aim of the article is to reconstruct a specific role of the European Union (EU) institutions within the to-date phenomenon of disintegration and to recognise supranational legal relations as a basis for the institutionalised disintegration. The concept of institutionalised disintegration is the author's proposal for using the EU acquis to create a new (autonomous) treaty regime of public international law. The empowered organs (under the Law of Treaties ${ }^{1}$ ) of this regime will be the EU institutions. Consequently, a new recognition of the EU institutions' role will be projected. Prior academic dogmas about the close connection between the institutional architecture and the system of international organisation will be critically examined. Recognition - in this context - means identifying the scopes and modes of institutionalised disintegration that is to shed new light on the dimension of supranational law. This light is especially evident at the lenses of current social phenomena. The method of legal reflections is a multifaceted reconciliation of functional and dogmatic approach, ${ }^{2}$ that is, to reconstruct legal phenomena. Therefore, this method will be systematised ${ }^{3}$ and mutatis mutandis applied. Firstly, concepts of institution and disintegration will be presented as a scope of factual recognition. Next, the article provides a de lege lata analysis of methods of implementation of the institutionalised disintegration within the EU legal framework. Eventually, relations between factuality and legal constructions will be reconstructed. Consequently, this reconstruction is to apply the method to present three to-date phenomena and to propose potential de lege ferenda postulates for the institutionalised disintegration.

\section{THE CONCEPT OF INSTITUTION}

The concept of institution combines historical and theoretical legal arguments. Historically, the institutions within the European Communities had been linked to the specificity of the solution adopted for each of the Community organs. The Treaty Establishing a Single Council and a Single Commission of the European Communities (Merger Treaty) introduced the unity of institutions, which were simultaneously organs for each of the Communities. ${ }^{4}$ It was a specific

\footnotetext{
1 Vienna Convention on the Law of Treaties (Dz.U. z 1990 r. nr 74, poz. 439), especially the Article 5.

2 Cf: R Michaels, 'The Functional Method of Comparative Law' (2006) Reimann M Zimmermann R (eds) The Oxford Handbook of Comparative Law, 339-342.

3 Cf: Z Ziembiński, Problemy podstawowe prawoznawstwa (Państwowe Wydawnictwo Naukowe 1980), 76.

4 [1967] OJ 152, 13.7.1967, 8.
} 
solution that formally separated Community law from public international law. The formal separation had been preceded by a functional interpretation of the Communities legal system's autonomy that was mapped by judicial judgements. ${ }^{5}$

The recognition of an institution, which has been above-reconstructed, stands against a primacy of the rules of public international law at the supranational level. The construction of the Communities law is to be described as a lex specialis or an exception from legal relations beyond the state under public international law. The justification for the described construction seems to be the postulate of theoretical recognition and (subsequently) autonomy of the new legal system under public international law. This proposal is of particular importance for reconstructing the scope for possible and up-to-date multiplication of the EU institutions as organs of new international organisations in the institutionalised disintegration context.

The concept of institution will be presented in three layers that stay in relation to legal analysis: formal, normative and realist.

\subsection{Formalist approach}

This layer is expressed by the conflict-based regime. The institution is a kind of reorganisation of powers (based on competences or objectives) - beyond Montesquieu's separation of powers model. ${ }^{6}$ Recognition of an institution is based on the establishment of a range of positive knowledge, ${ }^{7}$ the legitimacy of which stems from internal criticism. The system essence is to indicate a basis for conflictual rules.

\subsection{Normative approach}

The second one is to examine the systemic dimension of the institution and to limit the possibility of undermining the normative architecture of this system. Legal normativity mitigates and legally structures (precises) social objectives and expectations. Recognition of the system is an effect of tension between institutional architecture and constitutionalisation in public international law terms. ${ }^{8}$

5 Cf: Case C-6/64 Flaminio Costa v E.N.E.L. (15 Jul. 1964).

6 F Ryszka, O pojęciu polityki (Wydawnictwo Naukowe PWN 1992), 43-44.

7 K Tuori, Critical Legal Positivism (Ashgate Aldershot 2002), 28-30.

8 A Paulus, 'Whether Universal Values can Prevail over Bilateralism and Reciprocity', A Cassese (ed.) Realizing Utopia: The Future of International Law (OUP 2012), 89-104. 


\subsection{Realist approach}

The realist layer presents the institution as a place where ideas can turn into an objective claim. ${ }^{9}$ An institution becomes an embodiment and part of the mechanism of social life. The post-realist postulates for the rejection of the statecentric perspective and the reconstruction of the ideology of EU values are valid and require scientific reflection.

\section{THE CONCEPT OF DISINTEGRATION}

The author prepared a proposal for mapping of the phenomenon of disintegration within three current challenges that have legal, mixed and political spectres. Firstly, the national (not only constitutional) courts' legal turn towards EU law will be reconstructed. Secondly, constitutional rules, which discredit public international law, are a mixed dimension of disintegration. Finally, the concept of populism, which plays a pivotal role in the political disintegration process in the EU, will be analysed.

\subsection{Legal spectre of disintegration}

The first spectre of disintegration has an exclusively legal dimension and is based on the constitutional courts of Member States' allowance to express the last word in cases ruled before the Court of Justice of the EU (CJEU). This construction comes from an analysis of the Federal Constitutional Court of Germany (FCC) case law and points to the particular role of constitutional law as a method of appraising the relations between EU law and public international law. ${ }^{10}$ In this context, it is up to a constitutional court of a Member State to definitely decide on assessing the potential EU law changes.

The basis for this concept is a constitutional assessment of the supranational law: it shapes a new legal system in the sense of public international law, whether it is a normative updating of binding commitments in line with the EU objectives. A decision of the FCC shall indicate to the German legislature an appropriate procedure for accepting the proposed EU commitments. This practice may be

9 J Habermas, Strukturalne przeobrażenia sfery publicznej (Lipnik W Łukasiewicz M trs, PWN 2008), 110.

10 Cf: BVerfG, 2 BvR 987/10 vom 7.09.2011, BVerfG, 2 BvE 4/11 vom 19.6.2012, BVerfG, 2 BvR 1390/12 vom 12.09.2012, BVerfG, BVerfG 2 BvR 859/15, vom 05.05.2020. 
considered controversial in the EU law context. ${ }^{11}$ The assumption behind this thesis is the CJEU's exclusive jurisdiction over the Treaties ${ }^{12}$ and laws adopted on the basis of the Treaties. The national courts must decide according to a wellestablished line. ${ }^{13}$ On the other hand, the right to determine the validity of norms under primary law cannot be decided by national courts. ${ }^{14}$ The CJEU stresses that only a detailed analysis will confirm whether the similarity of cases is not only at first sight. ${ }^{15}$ This is the result of the complexity of EU laws' interpretation. Consequently, law-making activities in the sense of public international law that involve the EU institutions in the process of creating the legal system must be assessed by the CJEU and recognised by the Member States. Therefore, the national constitutional court cannot express the last word, as this method distorts the sustainability of integration within the EU legal system and violates the essence of EU law. On the other hand, the FCC points out three evaluation perspectives that are arguments behind the national courts' allowance to verify the changes in EU law.

The first argument is that the Member States are Masters of the Treaties (Herren der Verträge) ${ }^{16}$ If a Member State has the capacity to define the limits of international commitments, it should also have an impact on subsequent international law-making based on a supranational legal system. The indication of the boundaries of the development of supranational law does not stem from the need for disintegration but from the protection of competences by states. The FCC points out that the basic competence is the effective guarantee and protection of citizens' rights. However, the EU institutions exercise their competences (also in terms of objectives) only within the limits set and accepted by states. Therefore, the identification of EU law and public international law by constitutional rules can undermine the principle of good faith.

The second argument is called democratic and is based on the concept of civil rights. ${ }^{17}$ In this context, the interventions of the German judiciary in the scope and method of interpretation of EU law in the principle of equality context

11 J Habermas, The Crisis of the European Union: A Response (Ciaran Cronin tr, Polity Press: 2012), 127138.

12 This concept will be used as a description of the Treaty on the Functioning of the European Union (TFEU) [OJ C 326, 26.10.2012, 47] and the Treaty on European Union (TEU) [OJ C 326, 26.10.2012, p. 13-390].

13 Cf: 'necessary coherence' (Case C-461/03 Gaston Schul Douane-expediteur BV v Minister van Landbouw, Natuur en Voedselkwaliteit (6 Dec. 2005) para 15-16), 'essential unity' Ibidem para 21.

14 Ibidem, para 16-19.

15 Ibidem, para 20.

16 BVerfG, 2 BvR 1390/12 vom 18.03.2014, recital 161-166.

17 Cf: DH Scheuing, 'Deutsches Verfassungsrecht und europäische Integration' in Müller PCh Riedel E (ed.), Gemeinsames Verfassungsrecht in der Europäischen Union (Baden-Baden 1998), 186. 
remain particularly important. The EU's discourse of values and constitutional identity (Identitätskontrolle) has developed in a supranational dimension. However, the impact of Member States' constitutional law on EU law has always been a dialogue. The new CJEU case law line also opens up a new perspective of the disintegration-based interpretation of EU law.

Thirdly, the above-mentioned arguments need to be consolidated in the context of an admissible arbitrarity of the CJEU. The concept of arbitrarity is a technical term that indicates the FCC's recognition of the CJEU's authority to relax the process of applying EU law within limits that protect the constitutional identity of Member States. The basic elements and premises of this identity are the above two arguments. By contrast, the essence of constitutional identity is to protect the fundamental rights that EU citizens enjoy and that cannot be limited by law, either by the EU institutions or by the Member States. The FCC ruling of May 2020, ${ }^{18}$ which found that the European Central Bank's (ECB) decisions regarding its government bonds purchase program and, subsequently, the CJEU's judgment approving the ECB's actions taken as a result of an agreement between the governments of Member States exceeded the competences of these EU institutions, opened new optics on the reconstructed spectre of disintegration. The FCC argued that the CJEU's arbitrarity has resulted - all above - from a grossly incomprehensible method of proportionality review and a superficial explanation of the statement of the facts (context). The German court was, therefore, unable to accept the answer to the two questions referred for a preliminary ruling, ${ }^{19}$ which, in the view of that court, authorised it to give its last word.

The constitutional court's autonomous authority to limit the limits of the CJEU arbitrarily is the subject of much criticism. The two leading ones will be reconstructed. Firstly, the FCC should refrain from this type of practice because of the well-established claim to build dialogue between Member State authorities and the EU institutions and to avoid clashes. What is more, the concept of constitutional identity is strictly judicial in nature. During the work on the Lisbon Treaty, Germany suggested a special complaint procedure against EU law before national constitutional courts for violation of fundamental rights. ${ }^{20}$ The procedure was to be justified by the fear of ineffectiveness of The Charter of Fundamental Rights of the European Union without the participation of the Member States. Currently, constitutional identity is becoming a tool of populist regimes in the Member States that seek to limit the influence of EU institutions in controlling

\footnotetext{
18 BVerfG, 2 BvR 859/15, vom 05.05.2020.

19 Cf: BVerfG, 2 BvR 2728/13 OMT, Case C-62/14, Peter Gauweiler and Others v. Deutscher Bundestag (16 Jun. 2015) Gauweiler.
} 
the political actions taken by these States through German arguments. Secondly, voices supporting the demand for clarification of the rule of law have returned. The EU in particular has followed a legalistic-technocratic assessment of compliance with rule of law principles rather than endorsing a broader view of article 2 of TEU that combines all of its values. ${ }^{21}$ In this context, not only the summarisation by Member States of CJEU's rule of law rulings in the form of the EU rule of law mechanism, but also the action of national courts to identify those fundamental rights that should be formally recognised as the EU values contained within the EU primary law could contribute to the emancipation of citizens more than contesting the limits of the competences of the CJEU and the rest of the EU institutions.

The Dutch Urgenda judgement ${ }^{22}$ is an example that fits into the discussed spectre, but the position of the national court is the opposite of that of German doctrine. In this case, the Dutch court was the first to rule on the Kingdom of the Netherlands' supranational and international commitments on climate protection. Law theorists see a direct link between climate change law and the emancipation of the term 'cosmopolitan justice' ${ }^{23}$ Research on the methodology of law sees this ruling as 'law-finding 3.0'. ${ }^{24}$ This means that the court is not the only body that provides the remedy for inefficiencies of primary rules through the (secondary) rules of adjudication. ${ }^{25}$ The Urgenda case recognises public expectations and makes a legal evaluation that the Dutch government committed a general tort because its greenhouse gas reduction goal was not sufficiently ambitious. ${ }^{26}$ As a result, the European Convention for the Protection of Human Rights and Fundamental Freedoms (ECHR) builds a normative context for social expectations. ${ }^{27}$ However, the recognition of social expectations is the result of a democratic debate in the law-governed state. ${ }^{28} \mathrm{On}$ the other hand, it can be pointed

21 Cf: J Wouters, 'Revisiting Art. 2 TEU: A True Union of Values?' (2020) 5/1 European Papers, 255-277.

22 Urgenda Foundation v. State of the Netherlands, in which two judgments so far have been delivered: Court of First Instance, The Hague, 24 June 2015, Stichting Urgenda / Staat der Nederlanden, ECLI:NL:RBDHA:2015:7145 (Urgenda, The Hague Court of First Instance); Court of Appeal of The Hague, 9 Oct. 2018, Stichting Urgenda / Staat der Nederlanden, ECLI:NL: GHDHA:2018:2591 (Urgenda, The Hague Court of Appeal).

23 E Colombo 'The Quest for Cosmopolitan Justice in Climate Matters' (2017) 2 Nordisk Miljörättslig Tidskrift, $25-39$.

24 M Loth R van Gestel, 'Urgenda: Roekeloze Rechtspraak of Rechtsvinding 3.0?' (2015) 1849(37) Nederlands Juristenblad, 2598-2605

J van Zeben 'Establishing a Governmental Duty of Care for Climate Change Mitigation: Will Urgenda Turn the Tide?' (2015) 4(2) Transnational Environmental Law, 339-357.

27 Rome (Italy), 4 Nov. 1950, in force 3 Sept. 1953.

28 L Burgers 'Should Judges Make Climate Change Law?' (2020) 9:1 Transnational Environmental Law, $55-75$ 
out that the national court does not restrict the process of changing climate change law, which is the exclusive domain of democratic legislative power. The court's aim was to identify a threshold of inefficiency that violates supranational and international commitments.

In the institutionalised disintegration context, the national court's usage of the argument from the ECHR is particularly important. The EU's accession to this Convention requires reinstitutionalisation of the EU legal system, ${ }^{29}$ which is why the process is difficult. Environmental protection is an EU competence shared with the Member States. A direct application of the ECHR in order to influence the process of democratic change of law by the national court, which seems appropriate in view of the effectiveness of protecting the planet from disaster, should add impetus to the EU institutions. From a sociological perspective, the national court described social expectations in normative language. In this way, it opened the way for further changes - perhaps even primary law in the climate change law context.

\subsection{Mixed spectre of disintegration}

The mixed spectre of disintegration combines both legal and political arguments. Indeed, social facts can be assessed in both political and legal terms. However, in this approach, legal actions are taken to strengthen the political rejection of the integration. Methodologically, the ways of understanding international commitments will be validated. Technically, the constitutional rules, which discredit public international law, will be shown.

Public international law is not subject to a consistent methodological assessment. ${ }^{30}$ This situation is caused by discretionary at the level of both the identification of purposes of the law and its application by entities in public international law terms. Moreover, public international law is a unique system because it seems impossible to establish its external perspective.

The equality of entities under public international law implies equality in relation to reciprocal commitments. Methodologically, the state chooses a way of validation and commitments' relation to domestic law. ${ }^{31}$

The constitutional rules will be reconstructed as a technical approach. The proposal for amendments to the Constitution of the Russian Federation is a good

29 CJEU - Opinion 2/13 of the Court (Full Court), (18 Dec. 2014), para 38,158, 178.

30 Cf: A Gourgourinis, General/Particular International Law and Primary/Secondary Rules: Unitary Terminology of a Fragmented System (2011) 22/4 European Journal of International Law, 993-1026.

31 Cf: A von Bogdandy, Pluralism, direct effect, and the ultimate say: On the relationship between international and domestic constitutional law (2008) 6 (3-4) International Journal of Constitutional Law, 397-413. 
and to-date example of this phenomenon that will be a case study here. ${ }^{32}$ The current Constitution takes supremacy over international treaties because of its highest legal force. ${ }^{33}$ In principle, the international treaties prevail over the laws. On the other hand, the Russian Constitution provides that an integral part of a legal system is generally recognised principles and norms of international laws and international treaties. The coherent interpretation of legal notions allows for the identification that public international law plays a pivotal systemic role until it stays in accordance with constitutional norms.

The view that national constitutions should set the limits of the commitments to be accepted is common in the context of assessing the binding force of international treaties. However, such an assessment should take place before the State is bound (in a good faith) by the Treaty. Proposals for amendments that allow for political decisions at the national level on the need to apply norms derived from international legal commitments and on the subsequent interpretation of legal decisions issued by international bodies undermine the essence of public international law. In such a situation, it must be considered that any commitments of the State would be signed and ratified in blanco. Methodologically, such a commitment does not imply the need for a norm. Disintegration is an inconsistency between formal law and legal policy. The conception of in blanco commitments comes from and is justified in Scandinavian constitutionalism as a legislative practice. ${ }^{34}$ Historically, the ruler accepted the international commitment at the level of personal union, while national parliaments, in accordance with the theory of representation, introduced national laws, which were copies of the provisions of the treaties.

The Russian postulate de lege ferenda introduces legal uncertainty for others (parties of treaties) and reverses the paradigm of the general principles of public international law, which would dictate the a priori assumption of unwillingness to meet one's commitments and respect for the law, briefly - bad faith. This case shows that constitutional rules do not cut the state off from the process of integrating international law. These rules are aimed at the appropriation of the interpretation of public international law and political disintegration of international legal regimes by states.

32 Y Ioffe, 'The Amendments to the Russian Constitution: Putin's Attempt to Reinforce Russia's Isolationist Views on International Law?' (2020) Blog of the European Journal of International Law $<$ https://www.ejiltalk.org/the-amendments-to-the-russian-constitution-putins-attempt-to-reinforcerussias-isolationist-views-on-international-law/> accessed 20 August 2020. American Journal of International Law, 451-470.

34 M Wind, 'Do Scandinavian Care about international law? A Study of Scandinavian Judges' Citation Practice to International Law and Courts' (2016) 85(4) Nordic Journal of International Law, 281-302. 


\subsection{Political spectre of disintegration}

Populism is a political spectre of disintegration and a phenomenon that reconstructs current political discourse. The populist method undermines the recognition of norms, projects changes and creates a system of evaluation of social actions. ${ }^{35}$ Therefore, the introduction of three aspects that identify populism as a dimension of disintegration is inevitable.

The first aspect distinguishes the above-mentioned state-centric and the merely societal ${ }^{36}$ approaches to populism. The state-centric populism is a phenomenon and method of governing by populists. The fact of exercising power seems problematic due to the anti-political ontology of populism. ${ }^{37}$ The political essence of populism is also to question the norms that politically limit populist power. The discourse of fundamental rights and values must be considered as particularly questionable. This practice is observed among the EU Member States. The merely societal populism is a form of opposition to established social practices that have resulted in citizens being normatively excluded from decisionmaking processes. The populist aim is to regain sovereignty and participation by citizens. In this case, populists support supranational and transnational actions because a state-centric model of integration seems to be no longer enough.

Emancipation is to define, achieve and strengthen one's rights. Disintegration should foster the disintegration of normative systems that restrict rights. The concept of roguery derives from the Derridean rogue states and exposes threats to democracy from the state. ${ }^{38}$ Practically, the roguery is a violation of common norms and a striving for stratification within the integration project. Societal populism is aimed at the emancipation of fundamental rights and rejection of the states' roguery. Moreover, the state-centric populism does not want to find a logic behind the primacy of roguery and presents reasons for the emancipation of states' political rights. The main argument is that the model of political integration is exhausted. Moreover, the shared sovereignty weakens the Treaties, which are rooted in the political will of the Member States and responsibility in line with public international law. Populism as a political dimension of disintegration underlines that it is not possible to identify the substantive requirements of values

\footnotetext{
35 JW Müller, Co to jest populizm? (Sutowski M tr, Wyd. Krytyki Politycznej 2017), 10-15.

36 Cf: the concept of societal constitutionalism in: G Teubner, Constitutional Fragments. Societal Constitutionalism and Globalisation (OUP 2012).

37 JW Müller, (n 35) 55-56.

38 J Derrida, 'The Last of the Rogue States: The "Democracy to Come" Opening in Two Turns' (2004) 103 (2-3) South Atlantic Quarterly, 323-341.
} 
and the rule of law, ${ }^{39}$ as these are purely political arguments for full integration. Regardless of the assessment of the populist views expressed, the fact that the institutional assessment of the rule of law in the EU is a purely political procedure de lege lata is undeniable.

Despite the populist narrative, disintegration is not the essence of public international law. The state-centric populism recognises the weakness of European integration as a legally incomplete process and opposes the extension of legal integration at the same time. On the other hand, societal populism aims at disintegrating the social institutions that led to social and civic regress.

\section{METHODS OF THE INSTITUTIONALISED DISINTEGRATION: A DE LEGE}

\section{LATA LEGAL ANALYSIS}

In this part of the article, the above-presented factual recognition of institution and disintegration will be implemented into a legal context. Three methods of the institutionalised disintegration implementation are to provide a de lege lata analysis within the EU legal framework.

\subsection{The $\mathbf{E U}$ international agreements}

The first legislative method within the EU legal framework, which aims at formalising the concept of institutionalised disintegration, is based on the socalled EU international agreements. The essence of the method is the appropriateness of the system of EU institutions to shape commitments in accordance with public international law, which are differentia specifica of the EU legal system at the same time.

The pedigree of international agreements binding on the EU, which derive from the EU's external competences, is the so-called ERTA doctrine. ${ }^{40}$ The formal premise is that there must be a common policy as provided for by the Treaties' norm and that common rules ${ }^{41}$ shall be established as the legal framework for the potential agreement. In addition, common rules do not relate to the concept of common policy but refer to established objectives. Briefly, the establishment of common rules, which derive from the legal objectives and are related to the

\footnotetext{
39 L Trócsányi, 'Die Europäische Integration und die Mitgliedstaaten, Demokratie, Identität und Rechtsstaat' in Badó A, Deutsch-Ungarisches Symposium at University of Potsdam (Acta Iuridica Universitatis Potsdamiensis 2018) 19-29.

40 Cf: Cases C-22/70 Commission of the European Communities v Council of the European Communities (31 March 1971)

41 Ibidem, para 17-18, 24.
} 
concept of common policies, determines the existence of exclusive EU competence to conclude international agreements. If the EU does not have exclusive competence $^{42}$ to legislate, then such competence is implicitly shared by the Member States. The need for the participation of EU institutions, Member States and the third country is aimed at concluding the so-called mixed agreement. ${ }^{43}$ This is a particular solution of public international law, which establishes legal relations between the above-presented entities. Mixed agreements are an interesting solution in which Member States are obliged as sovereign entities and co-creators of the EU institutional system at the same time. Member States may define new competences in the line of public international law (Kompetenzkompetenz). The burden of efficiency of the system lies with the EU institutions, which guarantee consistency of application of the mixed agreement's norms. However, the definition of common rules makes the EU's an exclusive competence that the Member States shall accept.

The institutions may adopt a legislative act of the EU which may generate a non-treaty-based ${ }^{44}$ exclusive competence. The existence of such a norm allows competence to be built up through an international agreement (without the participation of Member States).

Neither the direct effect nor the obligation to implement the norm in absolute terms may be considered in the context of the use of the above techniques. This means that a competence contained in both primary and secondary EU law cannot be the basis for requiring EU institutions and Member States (in the case of nonexclusive competences ${ }^{45}$ ) to take legislative action within the meaning of public international law or for the ratifying and signing of the agreement. However, the definition of the EU exclusive competence in secondary law allows for the introduction of directly effective norms which constitute the institutional scope of potential agreements and complement the rights of those involved in the functional aspects of EU institutions.

Potentially, a legislative act (in particular a regulation), which, subject to an international agreement, guarantees a wide range of EU citizens' participation and new subjective rights related to the idea of democracy, can be imagined and reconstructed. Such a solution would give the EU exclusive competence to create such a regime. Only a potential international agreement would be the basis for the direct effect of the rights identified in the above-reconstructed piece of EU secondary law. The way it has been presented could involve the EU institutions

\footnotetext{
42 These competences are literally indicated in the Article 3 of TFEU.

43 Cf: the Article 216 of TFEU.

44 The legal basis for such actions in the Article 3(2) of TFEU.

45 This concept describes all competences that are not indicated in the Article 3 of TFEU and it is not necessary to be literally indicated in Articles 5 and 6 of TFEU.
} 
in developing subjective rights under the new international regimes. This would be a way of democratising and strengthening public international law through legislative acts of the EU.

\subsection{The doctrine of parallelism}

The second legislative method is based on the doctrine of parallelism. The notion of parallelism indicates the existence of at least two normative systems of norms which remain independent of each other and form a structure of equally binding norms for entities within systems ${ }^{46}$ If the original international agreement is considered as law-making, the mapping of parallelism is possible. This means that it is potentially possible to adopt new solutions within the framework of the legally foreseen legislation for the established system. However, if those bound by the norms of a kind of above-mentioned international treaties decide to conclude another autonomous international agreement, the relation between the established systems is parallel.

The Schengen Agreement is an example of the implementation of the doctrine of parallelism. The Agreement was the foundation for the free movement of persons without internal border controls. It was a systemic response to areas insufficiently regulated by Community law and a normative instrument that contributed to the realisation of fundamental freedoms. The doctrine of parallelism has influenced the development of the principle of a single institutional framework, which in turn has evolved towards the recognition and development of the acquis communautaire. This meant that the Schengen Agreement created independent norms within the regulatory area and that changes to the content of the agreement depended exclusively on the parties. Ultimately, in 1999, the Schengen acquis was included into the EU legal order. ${ }^{47}$

Parallelism-based law-making is linked to the complexity of the EU as a legal system. However, the postulate to create a single system based on the acquis communautaire is connected with doubts about the possibility of coherent integration of different areas of law. The paradigm of EU law is the principle of uniform (consistent) application of the law. On the other hand, lawmaking can be differentiated in accordance with the principle of efficiency. ${ }^{48}$ Therefore, on 27 May 2005, seven EU Member States signed the Convention on the stepping up of cross-border cooperation, particularly in combating terrorism, cross-border crime

46 R Schütze, 'Parallel external powers in the European Union' in Schütze R (ed) Part II - Foreignaffairs and the EU Constitution: vertical aspects (CUP 2014), 237-286.

47 OJ L 239, 22.9.2000, p. 13-18

48 See more: J Barcz, Konwencja z Prüm. Eksperyment prawotwórczy w Unii Europejskiej (2007) no. 3 Kozminski Law School Papers 
and illegal migration. The informal name of this treaty is the Prüm Convention (Prüm). The Prüm is a proof that it is quite difficult for a large group of Member States to agree on a common denominator. ${ }^{49}$ Especially, the legal scope concerns accelerated cooperation in the area of Justice and Home Affairs. In such situations, the similarity of legal cultures and community of interest is decisive. In this way, it is possible to agree with those Member States whose points of view are sufficiently consistent. If the need for quick action is, it is particularly important. Structurally, the Prüm emancipates the intergovernmental dimension of disintegration and limits the European Parliament's social control. In contrast to the Schengen, the Prüm is not to realise EU objectives, freedoms and rights. The Agreement is an instrument in the fight against terrorism, illegal migration and organised crime. The Prüm does not create an autonomous system of norms that are incorporated into the acquis. On the other hand, it is an independent and international legal system that accepts the scope of EU law and is responsive to secondary EU legislation.

Systemically, the Prüm was an element of the third pillar of the EU, whereas since the Lisbon reform it has concerned the so-called shared competences of the EU. Therefore, a change of approach to the protection of personal data was particularly important. The third pillar was not subject to the Data Protection Directive. ${ }^{50}$ When the European Parliament gave its opinion ${ }^{51}$ on the plans to conclude the Prüm, the protection of personal data appeared as a specific commitment of the parties in this context. Subsequently, the Council Framework Decision 2008/977/JHA of 27 November 2008 on the protection of personal data processed in the framework of police and judicial cooperation in criminal matters ${ }^{52}$ made it necessary for the Prüm acquis to adapt its norms. The approach to institutionalised disintegration under the Prüm, the author proposes to address it as the doctrine of reversed parallelism. In line with this doctrine, the system is involved in the process of disintegrating the coherence of the law and influences the legal response of institutions at the same time.

49 J Barcz, 'Włączenie postanowień Konwencji z Prüm do prawa UE' (2007) 5 EPS, 4-13.

50 Directive of the European Parliament and of the Council 95/46/EC of 24 October 1995 on the protection of individuals with regard to the processing of personal data and on the free movement of such data [1995] OJ L 281, recital 13.

51 European Parliament legislative resolution (2009/C 259 E/21) of 22 April 2008 on the initiative of the Federal Republic of Germany with a view to the adoption of a Council Decision on the implementation of Decision 2008/615/JHA on the stepping up of cross-border cooperation, particularly in combating terrorism and cross-border crime (11563/2007 - 11045/1/2007 - C6-0409/2007 - 2007/0821(CNS)) [2009] OJ C 259E, 111. 


\subsection{The EU institutions-based autonomous legal system}

The third method of institutionalised disintegration is a proposal for a complete legal system which is based on the EU institutions and corresponds to the norms of the Treaties. This normative situation refers to the reconstruction of EU law by the CJEU in the context of consideration of the legality of the Treaty Establishing the European Stability Mechanism by a part of Member States. ${ }^{53}$ The issue of the new treaty within the EU legal framework was the question of the legal basis that maintains the EU's primary law in relation to the new normative system and the possibility of using the EU institutions as bodies of a new international organisation.

The legal basis has been introduced in the TFEU. The European Council adopted a Decision in accordance with a simplified procedure (the so-called footbridge procedure) ${ }^{54}$ The application of the above procedure is a starting point for reflection on the legality of the institutionalised disintegration method. The CJEU has indicated that the footbridge procedure is appropriate as long as the revision does not go beyond the provisions of Part Three and does not interfere with exclusive EU competence. The CJEU then decided whether this revision would confer new powers for the EU. The claim that the amendment to the TFEU under consideration does not affect conferred powers is based on three arguments. ${ }^{55}$ Firstly, the indication in the Treaties of the competence to potentially conclude an international agreement, which must comply with EU law, by the Member States does not per se create either a new relation or a new legal system. Secondly, the revision is not to confer new powers for the EU. Thirdly, the EU institutions can be part of a new legal system provided that the new treaty is compatible with EU law. The CJEU notes that the nature of the provision determines neither the ability of Member States to conclude new agreements nor is it a lex specialis to the sovereign powers relating to the establishment of international legal systems. This means that, in the view of the CJEU, the Member States could have concluded this treaty even without changes to the TFEU. There are only two formal restrictions in the context of creating new legal systems. The EU, as a body of public international law, will not have new powers conferred by a new treaty. Moreover, the new Treaty will not interfere with the architecture of stability of

53 C-370/12, see more: Case C-370/12, Pringle v. Government of Ireland, Ireland and the Attorney General (27 Nov. 2012)

54 European Council Decision 2011/199/EU of 25 March 2011 amending Article 136 of the Treaty on the Functioning of the European Union with regard to a stability mechanism for Member States whose currency is the euro [2011] OJ L 91, 13. 
EU law, ${ }^{56}$ as this would be incompatible with the estoppel principle that states do not act against their commitments.

The adoption of such a free interpretation by the CJEU and the light criticism of Member States' formalism also make it possible to assume that it is possible to use the EU institutions under the new legal systems. The potential inclusion of the CJEU as an organ of a new international organisation stems from the personal (Member States), formal (compromis) and substantive (relation to EU law) aspects. ${ }^{57}$

The formal parallelism of the EU institutions allows for a new legal system. The relation to EU law does not have to be based on the texts of the Treaties and secondary EU law. The pursuit of values and objectives, the protection of fundamental rights and freedoms and the promotion of policies within the framework of non-exclusive competences are sufficient grounds here. Associated, but still controversial, is that the EU institutions may have new powers conferred under a new legal system. The condition is that these powers do not affect the EU conferred powers and do not interfere with the EU institutions' achievement of their objectives. ${ }^{58}$

The last thesis legally expresses the concept of institutionalised disintegration. However, this concept needs to be examined in up-to-date scientific debates on legal phenomena.

\section{RECOgNition OF LEgAL PHENOMENA: POSTUlative CRITIQUES}

The main aim of this part is to reconstruct and apply the method, which presents three to-date phenomena and determine the scope for scientific reflection on them. Phenomena will be analysed critically in order to propose potential de lege ferenda postulates for the institutionalised disintegration. The scientific reflection is based on a dogmatic approach and aimed at description, reconstruction and systematisation of dichotomies within the system and - as the consequence - the political of a law-making process. ${ }^{59}$ The law is actualised on two levels: linguistic and non-linguistic. Technically, this dichotomy can be reduced to two purposes: the textual establishment of a legal norm and the recognition of legal phenomena. ${ }^{60}$ The above-presented relation is the subject of reflection, which is

\footnotetext{
56 BVerfG, 2 BvR 1390/12 vom 12.09.2012, recital 233.

57 C-370/12, para 171-175.

58 CF: L Ehrlich, Prawo międzynarodowe (Wydawnictwo Prawnicze 1958), para 2-12.

59 Z Ziembiński, Teoria Prawa a Polityka i Zasady Legislacji(1994) LVI-4 Ruch Prawniczy, Ekonomiczny i Socjologiczny, 5-11.

60 S Wronkowska, Z Ziembiński, Zarys teorii prawa (ars boni et aequi 2001) 17.
} 
situated between axiology and the political. The concept of Political is not concentrated on axiology, but a conflictual basis for the political can only be recognised in an axiological way. The recognition of legal phenomena is a scientific activity that relies on the indication of the social argument behind the dogmatic approach. The process needs to find out a new paradigm of jurisprudence. The author's proposal is to introduce the methodological approach to jurisprudence that will be called the law-as-phenomenon.

The concept of law-as-phenomenon shows the law as an element of social relations and looks for a social validity of certain phenomena as the law at the same time. This concept aims to reconstruct the rules, which should be in line with the political measures and objectives that emerge at the stage of both lawmaking and application. The law-as-phenomenon deals with both social weaknesses of dogmatics and political seizure in theoretical analysis. Therefore, the scientific method based on the concept of law-as-phenomenon systemises certain actions, reconstructs the objective within the legal framework of the system and takes into account broader contexts than jurisprudence. The basic methodological aim is to expose insufficiencies of formal, normative or even realist approaches to the legal system.

The system consists of legal phenomena, which - in turn - define the law. The concept of law-as-phenomenon focuses on decoding text and dogmas in order to establish a systemic context. The concept of disintegration makes the above-mentioned process more complicated. The author's proposal is to decode considered normative orders by describing the complexity of legal phenomena. Disintegration must transfer the conflict to the level of another system, which will create a new perspective of conflict-based legal analysis. Three to-date issues will be examined.

\subsection{The concept of cross-currents}

Firstly, the concept of cross-currents will be recognised. ${ }^{61}$ This recognition presents legal phenomena that are able to influence the process of law reconstruction and social participation in international law. Cross-currents show a system that emerges as a proposal for systematising conflictual social assessments of the law within recognised institutions. ${ }^{62}$ Disintegration consists in a systemic approach to the different perspectives of interpretation of the law and the influence of social reality on the recognition of dominant opinions within

\footnotetext{
61 Cf: L Ehrlich (n 58) para 81-86.

62 Cf: A Dicey, 'Lectures on the Relation Between Law \& Public Opinion in England During the Nineteenth Century, edited and with an Introduction by Richard VandeWetering' ( Liberty Fund 2008) accessed 10 August 2020.
} 
social relation as the law. ${ }^{63}$ The concept of cross-currents distinguishes formal and factual relations. Formal relations are a difference between legal orders and contexts of recognition of certain rights that determine conflict within the new institutionalised system. The factual relations are reduced to political struggles and the problem of the authenticity of such systems. Authenticity can be described using the example of EU law, which initially depended solely on the will of Member States. Currently, Member States, institutions and citizens can influence the legal system in different ways. Therefore, the institutionalised disintegration must be multidimensional and multi-subjective in legal terms.

Historically, abstract legal norms in public international law and the apolitical nature of the institution were supposed to detach the processes of creating new legal systems from the influence of public opinion. ${ }^{64}$ In this way, the system is not oriented towards fulfilling the wishes of the states. The concept of law-asphenomenon is focused on maintaining the system as a level of reconstruction of legal phenomena that update in the moment of conflict. The presented concept does not identify the analysed system with a state that expresses common interests and is to be associated with other systems. The concept of cross-currents needs a systemic solution that will be presented below.

The original conception of conflict-of-law meta-rules describes a method of determining the role of public international law within the EU legal framework. EU law has emerged from public international law, established the self-contained regime and limited the scope of Member States' sovereignty. Thus, EU law has rejected a fundamental principle of public international law. At the same time, it strengthened the effet utile as a basis for the explanation of legal doubts. The view, which indicated a kind of specialisation of treaty regimes, expressed the probable direction of changes in public international law. This legal construction stays in strong relation to a new trend and technical proposal for the institutionalised disintegration. EU law becomes the basis for creating new legal systems within public international law. Moreover, the paradox of public international law shall be recognised here. On the one hand, public international law is legally assessed as a global legal phenomenon; on the other hand, it is a point of authority for this kind of assessment. The concept of conflict-of-law meta-rules allows to map relations between EU law and public international law. In this way, it will be possible to determine that a treaty-based system is more significant for the jurisprudence. Furthermore, the conflict-of-law autonomy of meta-rules makes it possible to determine whether it is possible to methodologically describe a new

63 CC Langdell, 'Dominant Opinions in England during the Nineteenth Century in Relation to Legislation as Illustrated by English Legislation, or the Absence of It, during That Period' (1906) 19/3 Harvard Law Review, 151-167 
system-type of law that combines the dichotomies of EU law and public international law.

The conflict-of-law meta-rules show the weaknesses of the formal understanding of the law and are a response to the understanding of international norms as ineffective inside the system. The theoretical disintegration of supranational relations creates a meta-rules-based system. This system is the basis for the recognition of legal phenomena that shape institution-based supranational relations.

\subsection{The COVID-19 pandemic}

The second phenomenon will be presented in the light of the COVID-19 pandemic. The need for a rapid political response has shown the weaknesses of the adopted international or supranational solutions. Moreover, Member States' responsibilities ${ }^{65}$ and warrant of fundamental rights ${ }^{66}$ are laxed. On the other hand, questions about EU empowerment and the division of competences between EU institutions and Member States seem to be reasonable. The institutionalised disintegration is the best proposal for identifying the above-mentioned issues and reducing the conflict-based laws.

The conflictual character of laws is an effect of an exclusively systemic reflection. The recognition of the law is based on values. However, laws have an appraisive character. ${ }^{67}$ The legal system is an order that functions as long as it finds justification in itself. Each legal norm is appraised by an algorithm that determines the role of the norm in the legal system. ${ }^{68}$ This is a strictly dogmatic approach, as the justification for subsequent norms is validated by means of higher-level acts. The basic norm constitutes all validities within the system. ${ }^{69}$ Therefore, such a norm is not conflicting.

65 F Paddeu, F Jephcott, 'COVID-19 and Defences in the Law of State Responsibility: Part I \& II' (2020) Blog of the European Journal of International Law $<$ https://www.ejiltalk.org/covid-19-and-defencesin-the-law-of-state-responsibility-part-i/ accessed 20 August 2020, $<$ https://www.ejiltalk.org/covid-19and-defences-in-the-law-of-state-responsibility-part-ii/> accessed 20 August 2020.

Cf: A Spadaro, 'Do the containment measures taken by Italy in relation to COVID-19 comply with human rights law?' (2020) Blog of the European Journal of International Law <https://www.ejiltalk. org/do-the-containment-measures-taken-by-italy-in-relation-to-covid-19-comply-with-human-rightslaw/> accessed 20 August 2020 .

67 The main thesis recognises the law as an essentially contested concept, it presupposes appraisive character of law. See more: WB Gallie, 'Essentially Contested Concepts' (1956) 56 Proceedings of the Aristotelian Society, 167-198.

68 A Aarnio, The Rational as Reasonable. A Treatise on Legal Justification (Springer 1987), 34.

69 J Habermas, Faktyczność i obowiązywanie: teoria dyskursu wobec zagadnień prawa i demokratycznego państwa prawnego (Romaniuk A tr, Wydawnictwo Naukowe Scholar 2005). 
However, EU law is more complex. The rationale for the Treaties can be sought in the sovereignty of the Member States, democracy at the EU level, the inevitability of the integration process, values and so on. It is important to reconstruct the absolute validity of EU law, which understands the law as a necessity to implement an accepted ontology. The ontology of EU law is supranational relations. The complexity of these relations was highlighted by the outbreak of the COVID-19 pandemic. ${ }^{70}$ The need for a rapid response is to-date, but the best solutions are related to the absolute validity of EU law. This is an external perspective that is dogmatically limited by the EU institutions. Supranational efficiency should be the ontology here. This ontology justifies the normative decisions that are made in the context of the fight against a pandemic as law. In this case, a number of basic norms, which constitute different systems and autonomous validities, can be drafted. Doubts relate to the limits of coherent participation of EU institutions and the unity of Member States' objectives. The scope of participation of the EU institutions indicates the institutionalised disintegration. The intergovernmental approach to this process supports the development of unity of Member States' objectives. On the other hand, the strong participation of EU institutions strengthens fundamental rights and ensures that measures are adopted in line with the EU objectives.

The form and assessment by the European Parliament of the European Council conclusions on the Post-COVID-19 Recovery Plan ${ }^{71}$ exemplify these concerns. Parliament underlines the democratic deficits that result from the laxed approach to the rule of law. ${ }^{72}$ The relation between democracy and the rule of law is of particular importance for the contemporary recognition of the legal system. ${ }^{73}$ The call for transparency in the post-pandemic EU recovery process should be directly linked to EU values. ${ }^{74}$ The instability and uncertainty of modern supranational relations dictate that the new legal systems should be linked to

70 Coronavirus disease 2019 is an ongoing pandemic. The World Health Organization firstly declared it to be a Public Health Emergency of International Concern and nextly, recognised it as a pandemic on 11 March 2020. As of 3 September 2020, more than 26 million cases have been reported across 188 countries and territories, resulting in more than 864,000 deaths.

71 European Parliament resolution B9-0229/2020 of 23 July 2020 on the conclusions of the extraordinary European Council meeting of 17-21 July 2020 [2020] P9_TA(2020)0206 <https://www.europarl. europa.eu/doceo/document/TA-9-2020-0206_EN.html> accessed 18 Dec. 2020.

72 Resolution on the conclusions of the extraordinary European Council meeting of 17-21 July 2020 2020/2732(RSP), para 9.

73 M Krygier, 'The Rule of Law: Legality, Teleology, Sociology' (2008) 2007-65 UNSW Law Research Paper.

74 a contrario: Resolution on the conclusions of the extraordinary European Council meeting of 17-21 July 2020 2020/2732(RSP), para 4. 
accountability, which is the civic control of disintegration of EU law. ${ }^{75}$ The institutionalised disintegration shall recognise this critique and be de lege ferenda democratic-oriented in the above-presented context.

\subsection{The need for inclusive participation}

The last phenomenon is based on the inefficiency of legal realism and communicative actions in law. In accord with Habermasian critique, the legal realism can only abstract social phenomena and shall be replaced by communication. ${ }^{76}$ This conception was updated. Currently two levels of communication are distinguished: centre- and participation-based. The centrebased level aims at deliberations that end in legislative decision making. ${ }^{77}$ The practical logic behind this approach is the equal participation of Member States in the process of amending EU primary law. Deliberative democracy emphasized the strong legitimacy of this law and embodied the postulate of a normative community. ${ }^{78}$ However, the Lisbon reform ${ }^{79}$ indicated that the attempt to develop procedures for an international law-making process was insufficient. The problem of legitimacy of the law focused on the direct use of normative solutions by citizens. The procedural sluice model of law-making is to be the basis for participation and democratically generated law. ${ }^{80}$ The European Citizens' Initiative is a formal stamp of the above-mentioned model. Citizens can initiate a drafting of EU secondary legislation, provided the required conditions are met. Nevertheless, both deliberative democracy and the formal sluice model of social participation are not enough now.

The main challenge for EU law theory is to identify a new systemic interpretation that rejects the state-centric approach. ${ }^{81}$ Citizens should not recognise the EU as a substitute for the Member States. The EU should be a space which mediates from the EU institutional framework and enhances citizens to

75 Resolution on the conclusions of the extraordinary European Council meeting of 17-21 July 2020 2020/2732(RSP), recital G-H.

76 J Habermas, The Crisis of the European Union: A Response (Ciaran Cronin tr, Polity Press: 2012), 119126.

77 J Habermas, Why Europe needs a constitution (2001) 11 New Left Review, 5-26.

78 BJ Singer, Pragmatism, Rights and Democracy (Fordham University Press 1999), 24-25.

79 Treaty of Lisbon amending the Treaty on European Union and the Treaty establishing the European Community (Dz.U. z 2009 r. nr 203, poz. 1569).

80 R von Schomberg K Baynes (ed), Discourse and Democracy: Essays on Habermas's Between Facts and Norms (SUNY Press: 2002), 243.

81 Cf: the criticism of Hegelian civil society theory in: Ch Mouffe, For a Left Populism (Verso 2018), 4450 . 
co-create rights. ${ }^{82}$ Civic participation in the generation of rights builds the conviction that the unity of rights is a condition for the creation of autonomous legal systems whose effectiveness is protected by the EU institutions. However, the discourse of rights is often inconsistent. Currently, personal and political rights' struggle among society indicates that social rights recognition may be a remedy for the inconsistency of rights. Social rights are vitally important for legal phenomena among society. The right to education or health protection shall be outlined. Common norms that are acceptable at the level of participation and seeking the identity of the rights granted will be named viable solidarity actions. Social rights as a source of personal and political rights' reinforcement are essentially significant. ${ }^{83}$ Furthermore, the viable solidarity action is a formula in which the sui generis transfer of social rights to the rest of the rights appears and consolidates the EU fundamental rights. Moreover, warrants of social rights are EU non-exclusive competences. The institutionalised disintegration based on building legal systems that implement social rights can influence the development of supranational law.

\section{Conclusion}

The scientific proposal for a sui generis reconciliation - or even consolidation - of institution and disintegration is a to-date legal challenge. The call for a reorganisation of supranational relations within conflictual phenomena and a limited EU legal system is possible, but it requires an interdisciplinary approach. The concept of institutionalised disintegration has been reconstructed in line with the adopted method. The EU institutions appear to be the formal framework to implement new legal solutions and to systematise social trends in the time of uncertainty. Moreover, the EU institutions are the lens through the perspectives of the legal system validities that are observed. Consequently, the disintegration becomes the basis for functioning the legal system that is independent from the EU and applicable beyond the Member States. The concept of institutionalised disintegration is an important assumption behind the legal debate on trends related to questioning the bright future EU law as it stands. This article presented a completely new recognition of basic concepts and phenomena within the EU political and legal framework. The specific relation between the dogmatic order of the analysed legal system and more functional approach to reconstructed social

82 N MacCormick, 'Constraints on Power: Fundamental Rights' in N MacCormick (ed), Institutions of Law: An Essay in Legal Theory (OUP 2007).

83 Z Bauman, Freedom From, In and Through the State: T.H. Marshall's Trinity of Rights Revisited (2005) no. 108 Theoria, 26. 
arguments resulted in the new systemic recognition of the EU institutions. This recognition is equal to the accountability of taken actions and democratic framework for potential multiplication of international organisations in the institutionalised disintegration context. The to-date issue is to use socio-political disintegration-based trends for the emancipation of fundamental rights, democracy and rule of law.

\section{Bibliography}

Aarnio A, The Rational as Reasonable. A Treatise on Legal Justification (Springer 1987).

Barcz J, Konwencja z Prüm. Eksperyment prawotwórczy w Unii Europejskiej (2007) no. 3 Kozminski Law School Papers.

Barcz J, 'Włączenie postanowień Konwencji z Prüm do prawa UE’ (2007) 5 EPS, 4-13.

Bauman Z, Freedom From, In and Through the State: T.H. Marshall's Trinity of Rights Revisited (2005) no. 108 Theoria, 13-27.

Bogdandy A von, 'Pluralism, direct effect, and the ultimate say: On the relationship between international and domestic constitutional law' (2008) 6 (3-4) International Journal of Constitutional Law, 397-413.

Burgers L, 'Should Judges Make Climate Change Law?' (2020) 9:1 Transnational Environmental Law 55-75.

BVerfG, 2 BvE 2/08 vom 30.6.2009

BVerfG, 2 BvR 987/10 vom 7.09.2011.

BVerfG, 2 BvE 4/11 vom 19.6.2012.

BVerfG, 2 BvR 1390/12 vom 12.09.2012.

BVerfG, 2 BvR 1390/12 vom 18.03.2014.

BVerfG, 2 BvR 2728/13, vom 21.06.2016.

BVerfG 2 BvR 859/15, vom 05.05.2020.

Case C-6/64 Flaminio Costa v E.N.E.L. (15 Jul. 1964).

Case C-22/70 Commission of the European Communities v Council of the European Communities (31 March 1971).

Case C-461/03 Gaston Schul Douane-expediteur BV v Minister van Landbouw, Natuur en Voedselkwaliteit (6 Dec. 2005).

Case C-370/12, Pringle v. Government of Ireland, Ireland and the Attorney General (27 Nov. 2012).

Case C-62/14, Peter Gauweiler and Others v. Deutscher Bundestag (16 Jun. 2015).

Colombo E, 'The Quest for Cosmopolitan Justice in Climate Matters' (2017) 2 Nordisk Miljörättslig Tidskrift 25.

Council Framework Decision 2008/977/JHA of 27 November 2008 on the protection of personal data processed in the framework of police and judicial cooperation in criminal matters [2008] OJ L 350, 60.

Danilenko G, 'The New Russian Constitution and International Law' (1994) vol. 88/3 
American Journal of International Law.

Derrida J, "The Last of the Rogue States: The "Democracy to Come" Opening in Two Turns’ (2004) 103 (2-3) South Atlantic Quarterly, 323-341.

Dicey A, 'Lectures on the Relation Between Law \& Public Opinion in England During the Nineteenth Century, edited and with an Introduction by Richard VandeWetering' (Liberty Fund 2008) accessed 10 August 2020.

Directive of the European Parliament and of the Council 95/46/EC of 24 October 1995 on the protection of individuals with regard to the processing of personal data and on the free movement of such data [1995] OJ L 281, 31.

Ehrlich L, Prawo międzynarodowe (Wydawnictwo Prawnicze 1958).

European Council Decision 2011/199/EU of 25 March 2011 amending Article 136 of the Treaty on the Functioning of the European Union with regard to a stability mechanism for Member States whose currency is the euro [2011] OJ L 91, 1.

European Parliament legislative resolution (2009/C 259 E/21) of 22 April 2008 on the initiative of the Federal Republic of Germany with a view to the adoption of a Council Decision on the implementation of Decision 2008/615/JHA on the stepping up of cross-border cooperation, particularly in combating terrorism and cross-border crime (11563/2007 - 11045/1/2007 - C60409/2007 - 2007/0821(CNS)) [2009] OJ C 259E, 111.

European Parliament resolution B9-0229/2020 of 23 July 2020 on the conclusions of the extraordinary European Council meeting of 17-21 July 2020 [2020] P9_TA(2020)0206 <https:// www.europarl.europa.eu/doceo/document/TA-9-2020-0206_EN.html> accessed 18 Dec. 2020.

Gallie WB, 'Essentially Contested Concepts' (1956) 56 Proceedings of the Aristotelian Society.

Gourgourinis A, General/Particular International Law and Primary/Secondary Rules: Unitary Terminology of a Fragmented System (2011) 22/4 European Journal of International Law.

Habermas J, Faktyczność i obowiązywanie: teoria dyskursu wobec zagadnień prawa i demokratycznego państwa prawnego (Romaniuk A (tr), Wydawnictwo Naukowe Scholar 2005)

Habermas J, Strukturalne przeobrażenia sfery publicznej (Lipnik W Łukasiewicz M trs, PWN 2008). 2012).

Habermas J, The Crisis of the European Union: A Response (Cronin C tr, Polity Press:

Habermas J, 'Why Europe needs a constitution' (2001) 11 New Left Review, 25-45.

Hart HLA, Concept of Law (2nd edn. Clarendon Press 1994).

Ioffe Y, 'The Amendments to the Russian Constitution: Putin's Attempt to Reinforce Russia's Isolationist Views on International Law?' (2020) Blog of the European Journal of International Law <https://www.ejiltalk.org/the-amendments-to-the-russian-constitution-putinsattempt-to-reinforce-russias-isolationist-views-on-international-law/> accessed 20 August 2020.

Krygier M, 'The Rule of Law: Legality, Teleology, Sociology' (2008) 2007-65 UNSW Law Research Paper.

Langdell CC, 'Dominant Opinions in England during the Nineteenth Century in Relation to Legislation as Illustrated by English Legislation, or the Absence of It, during That Period' (1906) 19/3 Harvard Law Review, 151-167.

Loth M Gestel R van, 'Urgenda: Roekeloze Rechtspraak of Rechtsvinding 3.0?' (2015) 1849(37) Nederlands Juristenblad, 2598-2605. 
MacCormick N, 'Constraints on Power: Fundamental Rights' in N MacCormick (ed), Institutions of Law: An Essay in Legal Theory (OUP 2007).

Michaels R, 'The Functional Method of Comparative Law' (2006) Reimann M Zimmermann R (eds) The Oxford Handbook of Comparative Law.

Mouffe Ch, For a Left Populism (Verso 2018).

Muller JW, Co to jest populizm? (Sutowski M tr, Wyd. Krytyki Politycznej 2017).

Opinion 2/13 of the Court [Full Court)] (18 Dec. 2014).

Paddeu F Jephcott F, 'COVID-19 and Defences in the Law of State Responsibility: Part I \& II' (2020) Blog of the European Journal of International Law <https://www.ejiltalk.org/covid19-and-defences-in-the-law-of-state-responsibility-part-i/ accessed 20 August 2020, <https:// www.ejiltalk.org/covid-19-and-defences-in-the-law-of-state-responsibility-part-ii/> accessed 20 August 2020.

Paulus A, 'Whether Universal Values can Prevail over Bilateralism and Reciprocity' in: A Cassese (ed.) Realizing Utopia: The Future of International Law (OUP 2012).

Ryszka F, O pojęciu polityki (Wydawnictwo Naukowe PWN 1992).

Schomberg R Baynes K (ed), Discourse and Democracy: Essays on Habermas's Between Facts and Norms (SUNY Press: 2002).

Scheuing DH, 'Deutsches Verfassungsrecht und europäische Integration' in Müller PCh Riedel E (ed.), Gemeinsames Verfassungsrecht in der Europäischen Union (Baden-Baden 1998).

Schütze R, 'Parallel external powers in the European Union' in Schütze R (ed) Part II Foreignaffairs and the EU Constitution: vertical aspects (CUP 2014).

Singer BJ, Pragmatism, Rights and Democracy (Fordham University Press 1999).

Spadaro A, 'Do the containment measures taken by Italy in relation to COVID-19 comply with human rights law?' (2020) Blog of the European Journal of International Law $<$ https://www. ejiltalk.org/do-the-containment-measures-taken-by-italy-in-relation-to-covid-19-comply-withhuman-rights-law/> accessed 20 August 2020. 2012).

Teubner G, Constitutional Fragments. Societal Constitutionalism and Globalisation (OUP

Treaty Establishing a Single Council and a Single Commission of the European Communities (Merger Treaty) [1967] OJ 152, 13.7.1967, 8.

Treaty of Lisbon amending the Treaty on European Union and the Treaty establishing the European Community (Dz.U. z 2009 r. nr 203, poz. 1569).

Treaty on European Union, OJ C 326, 26.10.2012, 13.

Treaty on the Functioning of the European Union, OJ C 326, 26.10.2012, 47.

Trócsányi L, 'Die Europäische Integration und die Mitgliedstaaten, Demokratie, Identität und Rechtsstaat' in Badó A, Deutsch-Ungarisches Symposium at University of Potsdam (Acta Iuridica Universitatis Potsdamiensis 2018), 19-29.

Tuori K, Critical Legal Positivism (Ashgate Aldershot 2002).

Vienna Convention on the Law of Treaties (Dz.U. z 1990 r. nr 74, poz. 439).

Wind M, 'Do Scandinavian Care about international law? A Study of Scandinavian Judges' Citation Practice to International Law and Courts' (2016) 85(4) Nordic Journal of International Law, 281-302.

Wouters J, 'Revisiting Art. 2 TEU: A True Union of Values?' (2020) 5/1 European Papers, 255-277. 
Wronkowska S Ziembiński Z, Zarys teorii prawa (ars boni et aequi 2001).

Zeben J van, 'Establishing a Governmental Duty of Care for Climate Change Mitigation: Will Urgenda Turn the Tide?' (2015) 4(2) Transnational Environmental Law, 339-357.

Ziembiński Z, Problemy podstawowe prawoznawstwa (Państwowe Wydawnictwo Naukowe 1980).

Ziembiński Z, Teoria Prawa a Polityka i Zasady Legislacji (1994) LVI-4 Ruch Prawniczy, Ekonomiczny i Socjologiczny, 5-11. 